\title{
Effects of Sea Level Variation on Biological and Chemical Concentrations in a Coastal Upwelling Ecosystem
}

\author{
Marilia M. F. de Oliveira ${ }^{1 *}$, Gilberto C. Pereira ${ }^{1}$, Jorge L. F. de Oliveira ${ }^{2}$, Nelson F. F. Ebecken ${ }^{1}$ \\ ${ }^{1}$ Civil Engineering Program, Federal University of Rio de Janeiro-UFRJ, Center of Technology, Fundão Island, Rio de Janeiro, \\ Brazil; ${ }^{2}$ Geography Postgraduate Program, Fluminense Federal University-UFF, Geoscience Institute, Niterói, Brazil. \\ Email: ${ }^{*}$ marilia@coc.ufrj.br
}

Received September $8^{\text {th }}, 2013$; revised October $8^{\text {th }}, 2013$; accepted November $8^{\text {th }}, 2013$

Copyright (C) 2013 Marilia M. F. de Oliveira et al. This is an open access article distributed under the Creative Commons Attribution License, which permits unrestricted use, distribution, and reproduction in any medium, provided the original work is properly cited.

\begin{abstract}
Oscillations in sea level due to meteorological forces related to wind and pressure affect the regular tides and modify the sea level conditions, mainly in restricted waters such as bays. Investigations surrounding these variations and the biological and chemical response are important for monitoring coastal regions mainly where upwelling shelf systems occur. A spatial and temporal database from Quick Scatterometer satellite vector wind, surface stations from the Southeast coast of Brazil and surface seawater data collected in Anjos Bay, Arraial do Cabo city, northeast of Rio de Janeiro State were used to investigate the meteorological influences in the variability of the dissolved oxygen, nutrients, meroplankton larvae and chlorophyll- $a$ concentrations. Multivariate statistical approaches such as Principal Component Analysis (PCA) and Clustering Analysis (CA) were applied to verify spatial and temporal variances. A correlation matrix was also verified for different water masses in order to identify the relationship between the above parameters. A seasonal variability of the meteorological residual presents a well-defined pattern with maximum peaks in autumn/winter and minimum during spring/summer with negative values, period of occurrence of upwelling in this region. This lowering of the sea level is in accordance with the increasing of nutrients and meroplankton larvae for the same period. CA showed six groups and an importance of the zonal and meridional wind variability, including these variables in a single cluster. PCA retained eight components, explaining $64.10 \%$ of the total variance of data set. Some clusters and loadings have the same variables, showing the importance of the sea-air interaction.
\end{abstract}

Keywords: Meroplankton Larvae; Nutrient Concentrations; Coastal Waters; Brazilian Upwelling

\section{Introduction}

The upwelling shelf systems as reservoirs for biological and chemical concentrations depend as much on the scales and rates of phytoplankton new production as on the dynamical processes that govern heterogeneity of particle sedimentation within the shelf [1]. Tropical seas occurs greater light penetration in the water column, varying little throughout the year which makes it an optimum condition for phytoplankton primary production and so, increasing the concentration of chlorophyll $a$.

In coastal regions subject to the influence of coastal upwelling, phytoplankton production can be greatly affected locally. The transport to the surface of deep water cooler, nutrient rich favors the occurrence of major phytoplankton production peaks that can determine the oc-

${ }^{*}$ Corresponding author. currence of maximum abundance of zooplankton populations [2]. Internal tides and coastal upwelling have important roles in marine ecosystems due to the mixing of water masses with potential redistribution of heat, salt and nutrients to the biological system. There are numerous mechanisms whereby tides might influence shoreline biological and chemical concentrations. Flooding tides can dilute near shore sources and reduce these concentrations. Ebbing tides drain the water from land to sea and spring tides provide a hydrologic connection between the sea and biological and chemical sources at the high water line and upper reaches of the tidal prism in tidal wetlands and subterranean estuaries within the beach aquifer [3].

A flow pattern observed in continental shelf and slope associated with tidal currents is highly modified by factors such as topology of coastline, background bathymetry and climatic conditions of the region. These currents 
can generate resuspension of sediments and nutrients from the bottom, increasing the mixing layer. Barotropic and baroclinic tides can cause a mixing in the water column, leading an important impact on biological production due to the upward flow of nutrients from the layers below the euphotic zone [4].

Coastal regions are areas with high rates of productivity in the marine environment, and are the areas that suffer most from the impacts of human activities on fish stocks and the pollution from the large coastal urban centers. Human activities such as fishing, shipping and recreation are also centered near the shorelines, where knowledge of the tidal movement is necessary. These coastal regions are areas where tidal ranges are most evident and can, associated with elevated wave energy, cause coastal erosion. Hydrographic mesoscale structures in the South Atlantic subtropical ocean near the Brazilian coastline show a high variability in a environmental conditions, with physical and biological characteristics extremely relevant with mechanisms of ocean-atmosphere (OA) interactions [5]. The upper ocean plays a fundamental role in building a structure of both wind-driven and thermohaline circulation. Large-scale meteo-oceanography patterns are in accordance with the OA interactions through the South Atlantic subtropical high-pressure system, a predominant air mass above the central region of the South Atlantic Ocean basin, centered near $30^{\circ}$ latitude that induces the currents of upper ocean due to the wind-driven forces [6]. This air mass modulates the zonal wind field and when easterly winds are dominant in the southeast coast of Brazil, high atmospheric pressure enhances the inflow of Atlantic waters through the Arraial do Cabo region. The water inflow leads to occurrence of coastal upwelling due to the anticyclonic gyre moving Tropical Waters (TW) off the coast followed by the up-flow of the deeper South Atlantic Central Water (SACW) mass, with a decrease in sea surface temperature and a maximum of surface nutrient concentrations located in the coastal area. This pattern is predominant in spring-summer period. On the other hand, in autumn-winter period, when southwesterly winds prevail, lower atmospheric pressure increases the flow parallel to the coastline and the oceanographic and biological structures are different. These physical alterations also induce changes in the distribution of these variables.

Oscillations in sea level due to meteorological driving forces related to wind and pressure occur at different scales and frequencies in all coastal regions. Interactions between meteorological and oceanic variables affect the regular tides and modify the sea level conditions, mainly in restricted waters such as bays. The patterns of tidal waves on the continental shelf are scaled down, being strongly influenced by Kelvin wave dynamics and by basin resonances [7]. Tides on the continental shelf are predicted using the harmonic analysis method which is based in tidal variations represented by $\mathrm{N}$ harmonic constituents. These constituents can then be used to provide reliable predictions for future tides at the respective point [8]. Predictions for reference stations are prepared from the astronomical arguments using local constituents determined by previous analysis and do not take into account meteorological influences. Thus, the observed and predicted values of the sea level variations are normally different. Storms are the main cause of these sea level variations known as storm surge and the action of wind stresses on the surface water is the principal factor involved in the generation and modification of the sea level height $[7,9,10]$. The tendency for surge peaks that occur most often on the rising tide in UK North Sea coastline, using numerical models was confirmed by [11]. They concluded that this pattern occurs independently of the phase between tide and surge. The models made it possible to separate the contribution to interaction from shallow water and bottom friction. [12], see also [13] used an analytical model to show that the shallow water effect becomes dominant for great tidal amplitudes in depths of $10 \mathrm{~m}$ or less.

The variability of productivity in upwelling shelf regions must consider the need for a better understanding of the mean distributions and variability of nutrients, as well as the physical-biological coupling, in these regions. Upwelling systems are characterized by the ascension of cold and rich in nutrients water that disturb ecosystem dynamics and increases the environmental heterogeneity [14]. Then, the knowledge about the sea level height variations in shelf regions is very important not only for marine services but also for designing and constructing onshore structures, protection of coastal regions, and mainly for monitoring the changes in marine ecosystems [15].

This study is part of the research developed by the Federal University of Rio de Janeiro-Civil Engineering Program in remote monitoring systems of environmental impacts in coastal regions in order to develop trophic dynamic models to be used in the National Plan and Regional Coastal Management or in any other aquatic system. To continue the study of biological and chemical distribution and meteo-oceanography patterns [16], we have also verified the relations between them and tidal influence in the Arraial do Cabo region. This place is known for its active wind induced shelf upwelling [17]. Seasonal variability of the South Atlantic high pressure system is associated with the occurrence of this phenomenon.

Upwelling is set up in the summer by large-scale, high-speed winds northeasterly blowing over the region off the coast [18]. This point divides Brazilian coast in environments with tropical and subtropical features in a 
small spatial scale [19]. Moreover this place is very attractive for the tourist and recreational activities, contributing to the local economy, but human activities are significantly affecting the coastal ecosystem [20]. The influences of meteorological patterns in the sea level response at Arraial do Cabo was verified using the Quick Scatterometer satellite vector wind over the South Atlantic Ocean near the coast of the study area, surface stations and seawater harvest sample, applying statistical tools such as multivariate analysis.

The aim of this study is to investigate the influences of the sea level variations in the biological and chemical responses at Arraial do Cabo due to meteorological forcing, considering the main water masses in the southeastern Brazilian shelf.

\section{Material and Methods}

\subsection{Study Area}

In order to investigate the sea level dynamic in Arraial do Cabo and its influence in the variability of the studied variables, we verified the spatial and temporal meteorological systems related to the sea level variations. This research is a continuity of [16], in which we used the same study area with the local points from satellite data, surface weather station, tide gauge station and sample water harvest in Anjos Bay.

This study area is under influence by the South Atlan- tic high-pressure system and is situated on the southeast coast of Brazil near Arraial do Cabo city, (Figure 1).

\subsection{Climatological Description of the Study Area}

This region is influenced by persistent high pressure over the South Atlantic Ocean that enhances northeast flow across the area. This circulation is periodically disturbed by the passage of frontal systems caused by migrating anticyclones that move from the southwest across the northeast in the southeast coast of Brazil.

During the summer (Figure 2(a)), the subtropical high, over the continent, becomes weaker than winter (Figure 2(b)), moving southerly and on its western side the winds blow northeasterly towards the southeastern coast of South America and they are more intense in the southeastern coast of Brazil. Therefore, in the north region of the Brazil Malvinas Confluence (BMC), at $38^{\circ}-40^{\circ} \mathrm{S}$, there is an intensification of the northerly winds and a weakening of the southwesterly winds which is difficult for the track of the cold fronts that reach the south and southeast coast of Brazil [21]. This seasonal variability is one of the most important factors related to the occurrence of upwelling in the region of Arraial do Cabo, where the winds blow along the coastline from north to south push the surface waters offshore on summer periods [18].

The mean surface circulation of the South Atlantic

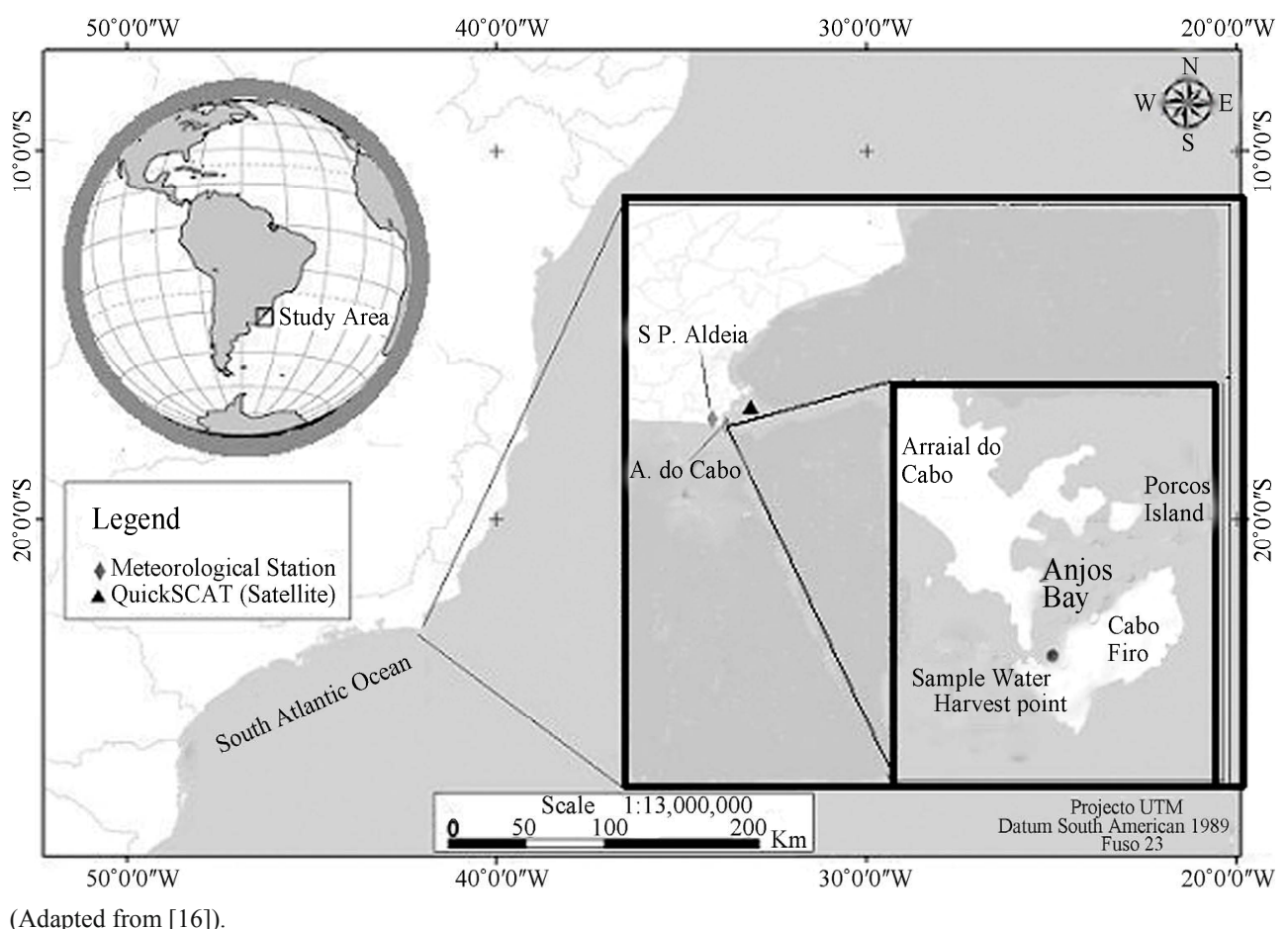

Figure 1. Study area with the points representing Sâo Pedro d'Aldeia surface weather station $\left(22^{\circ} 57^{\prime} \mathrm{S} / 42^{\circ} 06^{\prime} \mathrm{W}\right)$ and Arraial do Cabo $\left(22^{\circ} 57^{\prime} \mathrm{S} / 42^{\circ} 14^{\prime} \mathrm{W}\right)$ tide gauge station, satellite QuickSCAT winds in $22^{\circ} 52^{\prime} \mathrm{S} / 41^{\circ} 52^{\prime} \mathrm{W}$ and water harvest point in $23^{\circ} 00^{\prime} \mathrm{S} / 42^{\circ} 00^{\prime} \mathrm{W}$ (Anjos Bay). 


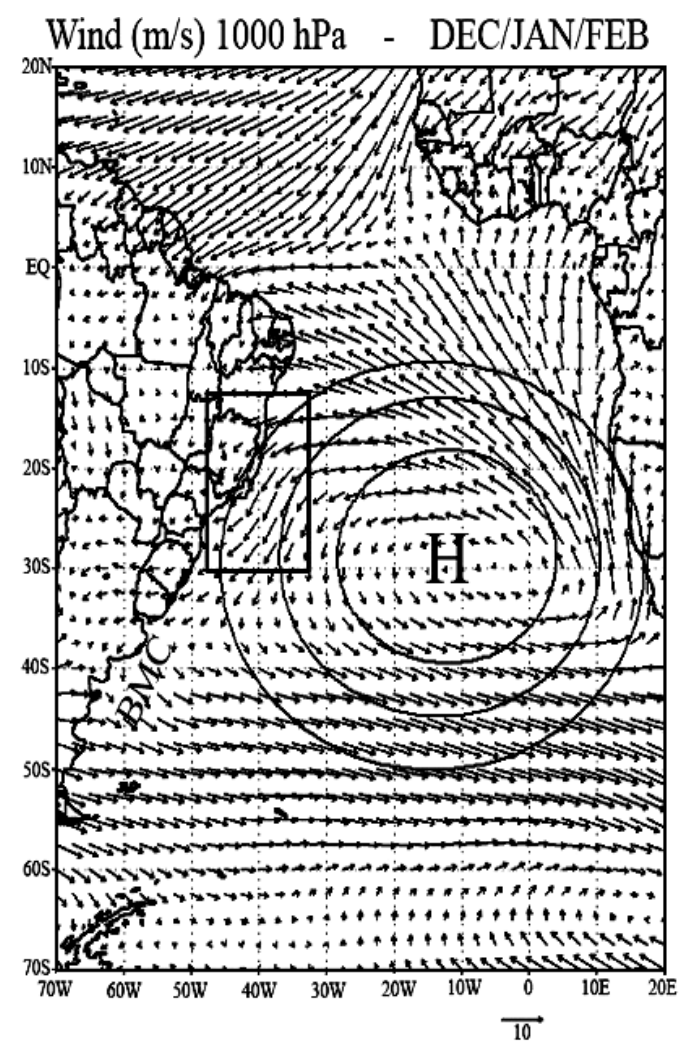

(a)

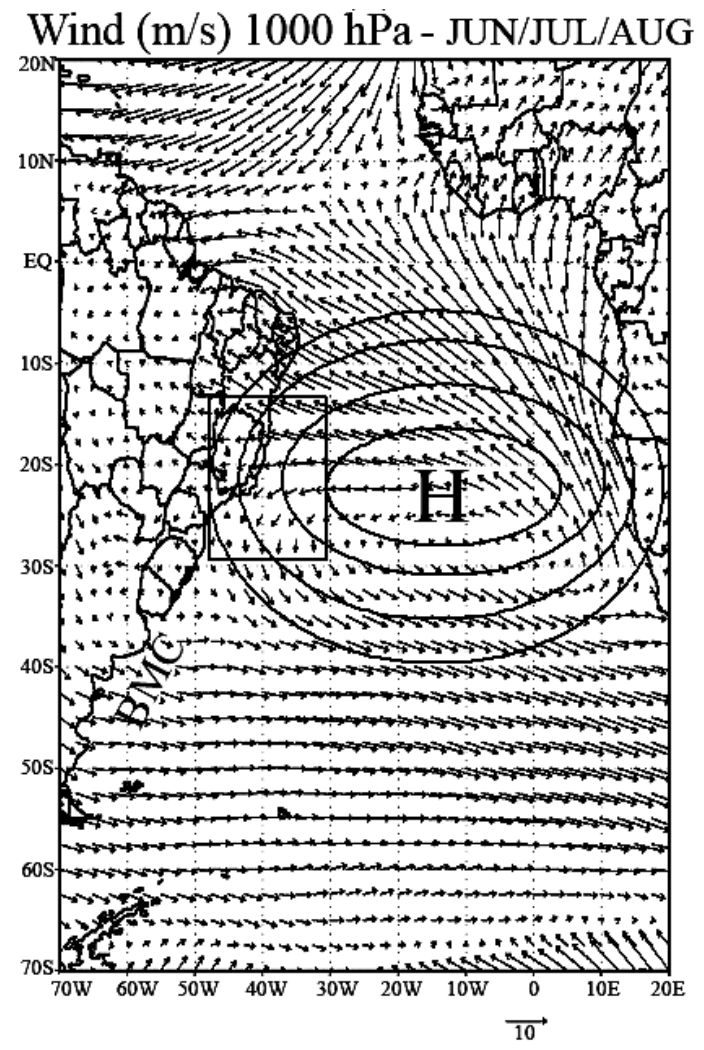

(b)

(Adapted from [16]).

Figure 2. Surface wind-flow pattern with a scheme of the South Atlantic high-pressure system for summer (a) and for winter (b). The circles represent the isobars and the positions of the high centers moving slightly during the year; the squared shows the winds blowing over the study area; BMC Brazil Malvinas Confluence region.

Ocean is dominated by a closed system known as the South Atlantic subtropical gyre that is composed of several ocean currents and on the western boundary of this gyre it has the Brazil Current (BC) [22]. Thus, the Southwest Brazilian coastline is characterized by the presence of the $\mathrm{BC}$, a warm current of the South Atlantic that goes away inshore from the northern Brazil over a continental shelf toward the south, carrying the TW from the vicinity of the Equator [23]. This current makes this region oligotrophic; therefore, in some areas occur a seasonal wind-driven upwelling of cold, nutrient-rich SACW mass, benefiting on biological productivity. In Arraial do Cabo, the positioning of the Cabo Frio island $\left(23^{\circ} \mathrm{S}, 42^{\circ} \mathrm{W}\right)$ forms the small $\left(45 \mathrm{Km}^{2}\right)$ and narrow ( 10 m deep) Anjos Bay (Figure 1).

The latitudinal position of the $\mathrm{BC}$ is characterized by a seasonal variation. It means that, on average during the austral summer, the $\mathrm{BC}$ extends more southwards. The opposite occurs in winter and $\mathrm{BC}$ extends more northwards [22]. The transport of $\mathrm{BC}$ that follows the curve of annual variation of wind shear over the subtropical basin with a maximum during the summer (Figure 3) and minimum during the winter (Figure 4) was suggested by
[24].

The interest in monitoring environmental impacts in this coastal region is because it can be considered yet a pristine area and the hydrologic conditions are strongly influenced by the wind pattern that influences the distribution of water masses. Winds that blowing from northeastern and the Earth's rotation, result in a shunting of the nutrient-depleted surface $\mathrm{TW}$ of $\mathrm{BC}$ to offshore followed by the up-flow of the deeper ( $\sim 300$ meters) and nutrient-rich of SACW mass [20]. Upwelling events and inorganic nutrients are then supplied to euphotic zone by the exchange of water between nutrient-depleted surface water and nutrient-rich deeper water. When the inverse wind pattern occurs, the winds blow from south and southwestern due to the passage of cold fronts and the oligotrophic TW back to the coast. Thereby, this meteorological event leads to the occurrence of surges which modify the tidal amplitudes due to interactions between winds, shallow water and bottom friction. These processes have a direct impact on the quantity and composition of the phytoplankton communities, modifying the trophic structure [26]. In the other hand, elevated nutrient concentrations are the main origin of coastal eutrophica- 


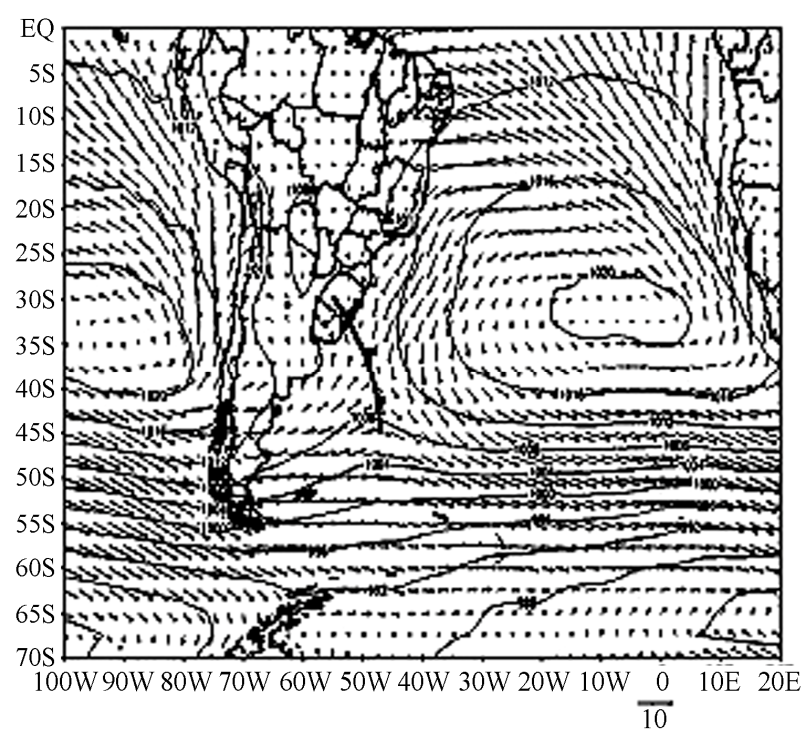

(a)

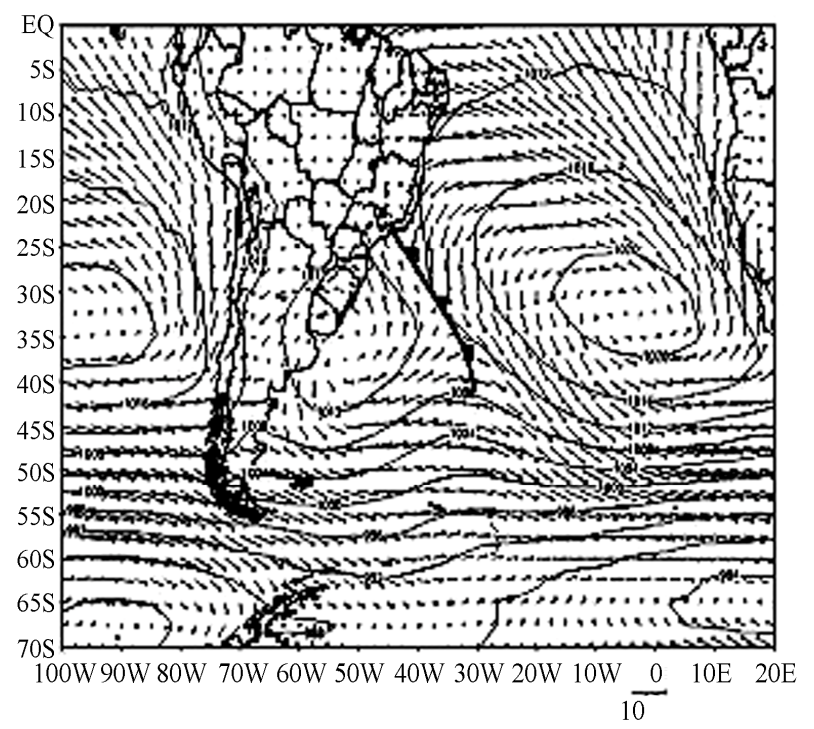

(c)

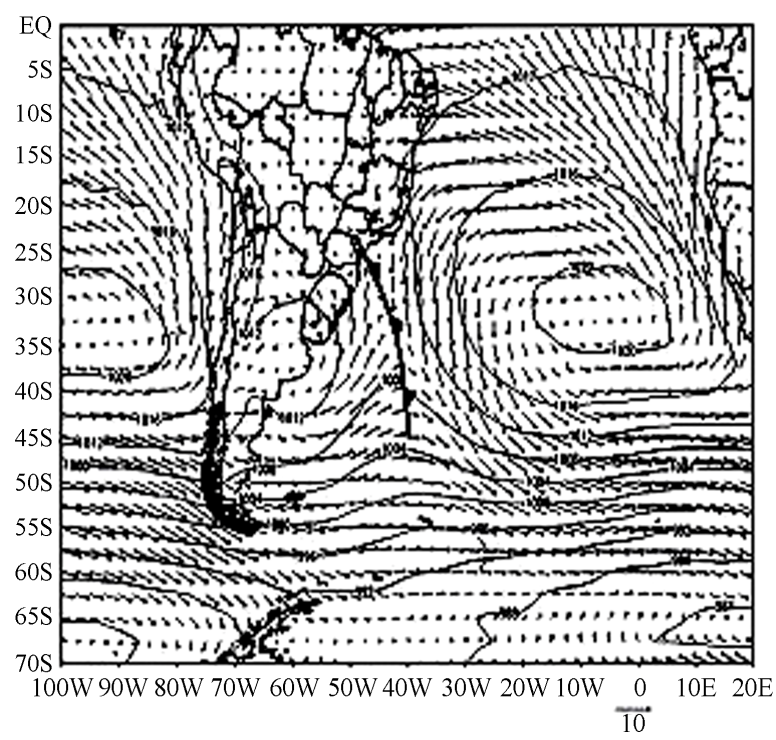

(b)

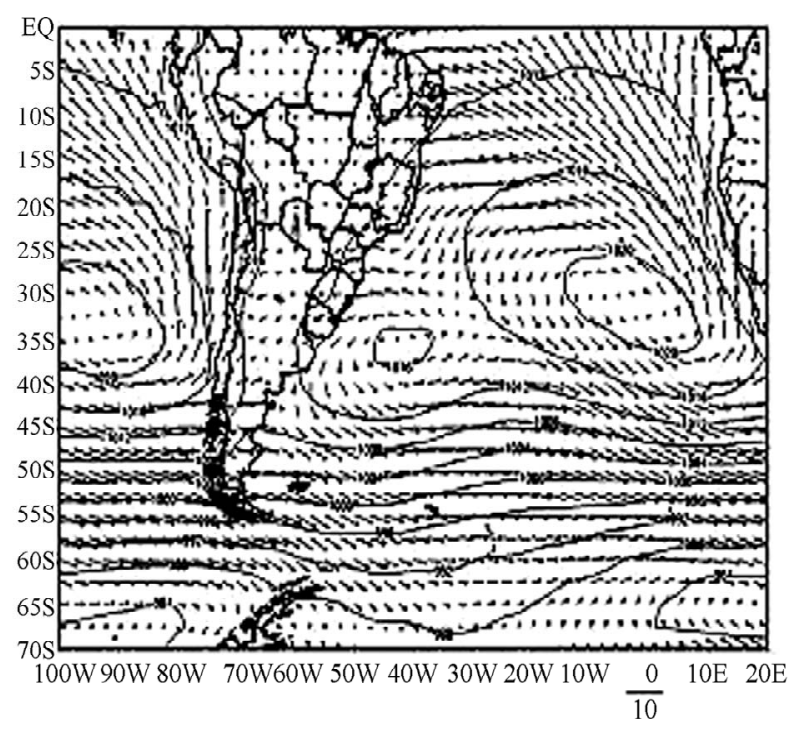

(d)

Source: [25].

Figure 3. Average fields of sea level pressure (hPa) and $10-\mathrm{m}$ above ground level wind $(\mathrm{m} / \mathrm{s})$, for cold fronts passages at $\left(30^{\circ} \mathrm{S}\right.$ e $47.5^{\circ} \mathrm{W}$ ), in summer months. The contour interval is $4 \mathrm{hPa}$ and the location of surface cold front is also marked.

tion processes and their monitoring allows direct estimates of the degree of contamination, and obviously making possible their management [27,28].

\subsection{Astronomical Tides and Meteorological Residual}

The astronomical tide pattern at Arraial do Cabo station is mixed tide. The mixed tides are a type of tide in which the diurnal and semidiurnal oscillations are important factors. The tide is characterized by large differences in height between two high tides (HT) or two consecutive low tides (LT). There are usually two HT and two LT each day, but occasionally the tide can become diurnal. Figure 5 shows the tidal ranges (vertical distance between high tide and low tide) in Arraial do Cabo that is around 1.20 meter in the largest peaks of low tides due to the diurnal influence, considering periods of spring tide.

The semidiurnal constituents $\mathrm{M}_{2}$ (principal lunar) and $\mathrm{S}_{2}$ (principal solar) have the greatest amplitudes. The diurnal constituents $\mathrm{O}_{1}$ (principal lunar) and $\mathrm{K}_{1}$ (declinational luni-solar) are also present as well as the shallow water constituents $\mathrm{M}_{4}$ (quarter diurnal lunar), $\mathrm{MNS}_{2}$ (semidiurnal harmonic shallow water) and $\mathrm{MS}_{4}$ (quarter diurnal harmonic shallow water), which indicate the influence of the propagation of the tide wave in the conti- 


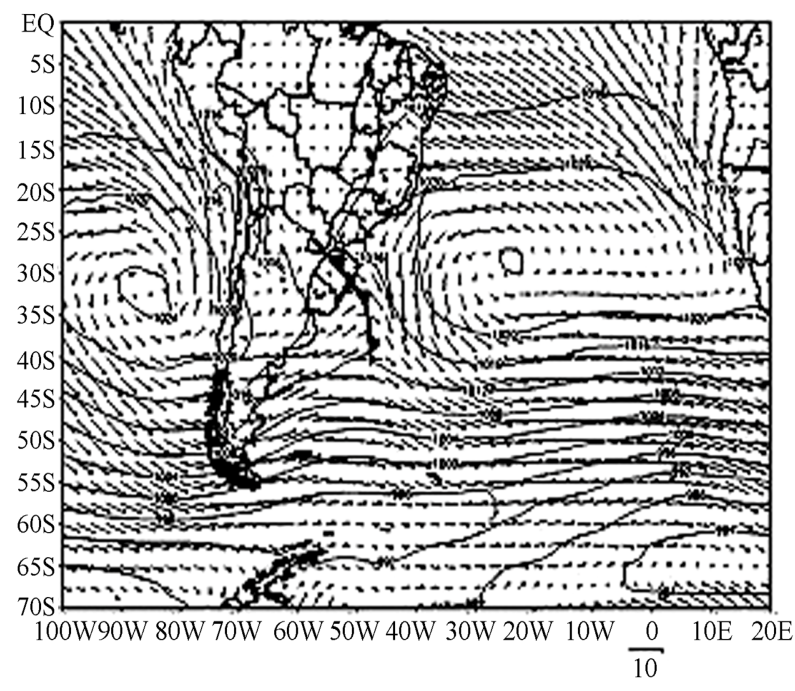

(a)

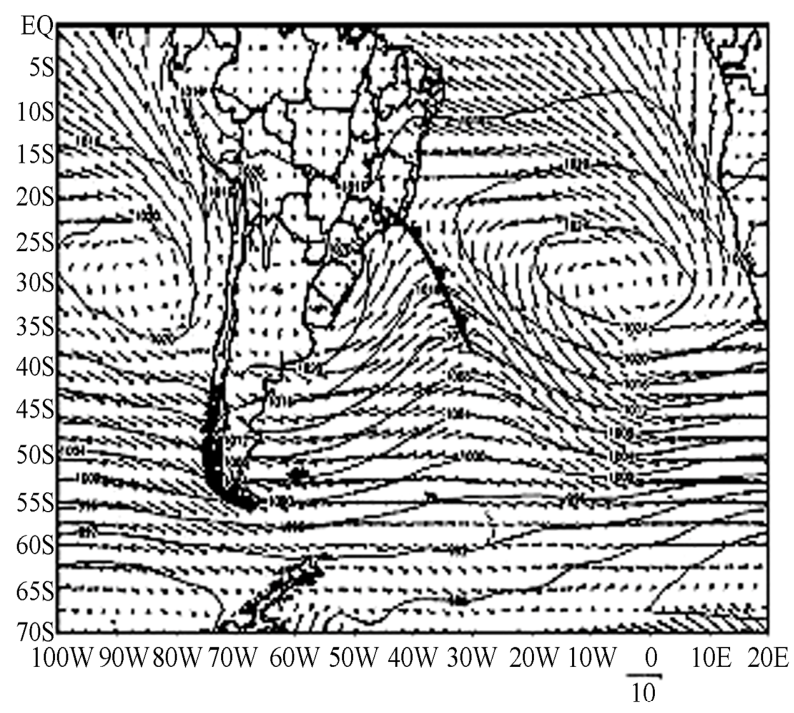

(c)

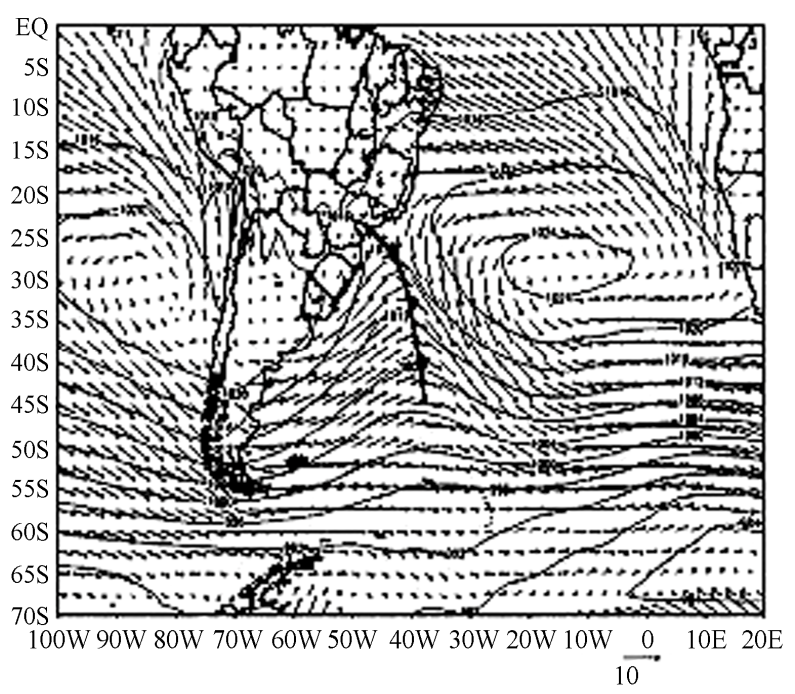

(b)

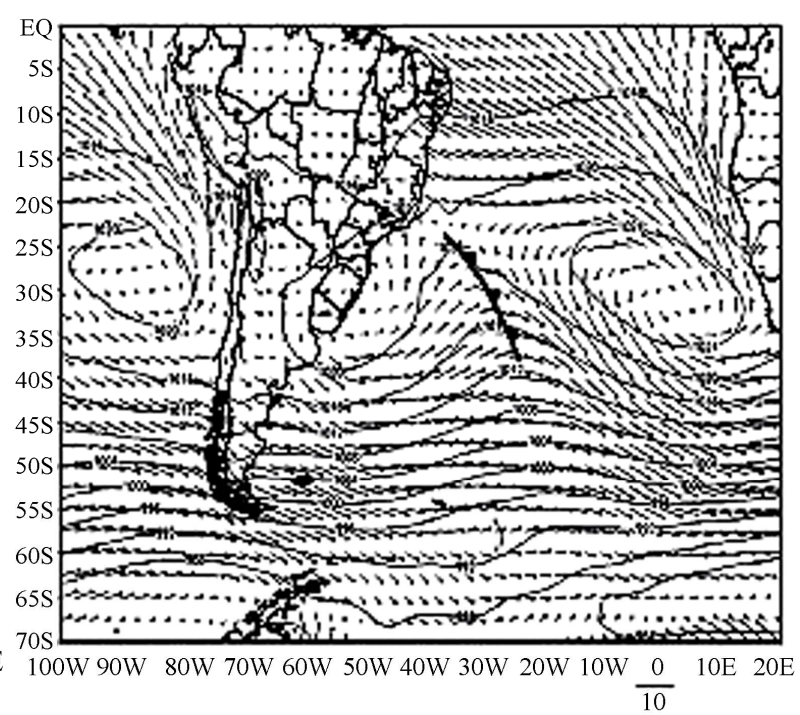

(d)

Source: [25].

Figure 4. Average fields of sea level pressure (hPa) and $10-\mathrm{m}$ above ground level wind $(\mathrm{m} / \mathrm{s})$, for cold fronts passages at $\left(30^{\circ} \mathrm{S}\right.$ e $47.5^{\circ} \mathrm{W}$ ), in the winter months. The contour interval is $4 \mathrm{hPa}$ and the location of surface cold front is also marked.

nental shelf [10]. The regular and predictable oscillation of the tides is modified by meteorological patterns, being the principal ones the atmospheric pressure and winds acting on the sea level. These irregular changes, known as surge are the non-tidal residuals and can be defined as the difference between the observed and predicted levels. The non-tidal residual is alternatively called the surge or storm surge, non-tidal component or meteorological residual [10]. Figure 6 shows a 30-day hourly height records of the predicted tide at the Arraial do Cabo tide gauge station, showing the tidal regime with distortions by the influence of the shallow water as well as the observed tide and the variation of the meteorological residual.

Recurrent upwelling events provide cold and rich in nutrients water to the coastal zone throughout the year. The semidiurnal tides, ranging between 1.0 and $2.4 \mathrm{~m}$, play a key role in these systems, forcing the upwelled water into the embayment [29]. Many shallow water larvae migrate according to the tidal frequencies from one location to another in synchrony with the tidal cycle. The most common form of synchronized migration with the tides is the intertidal migration that consists of the movement of organisms into and out of the intertidal zone in each oscillation of the sea level on the ebb and flood tide [30]. Decapods are sensitive to the light cycle, and within estuaries, larval release and upward vertical migration occur most frequently on nocturnal high tides. These behaviors occur in a wide range of planktonic animals and 


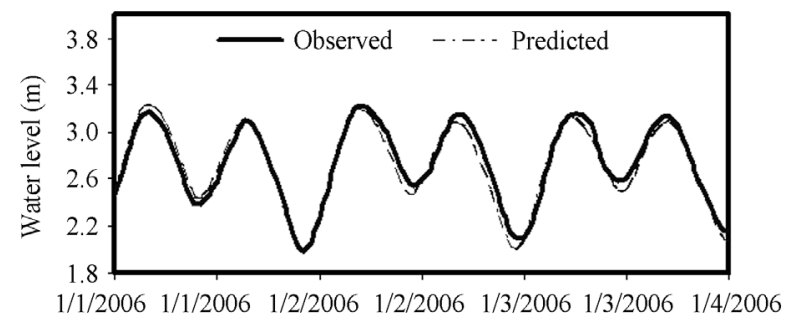

Figure 5. Series of 72 hourly heights of the observed and predicted tides at Arraial do Cabo tide gauge station, starting January 1, 2006. It can verify the mixed regime: semidiurnal with diurnal influence. The smallest peaks of LT characterize this local tidal regime observed on days $1-2$ at 2300 local time.

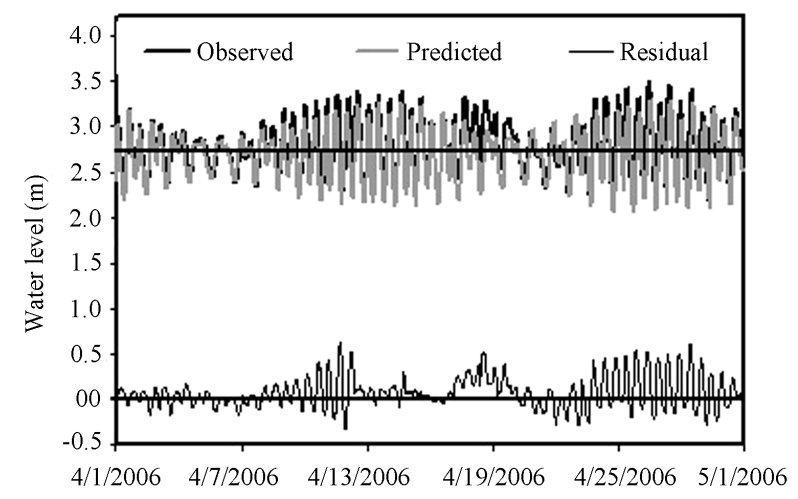

Figure 6. Series of harmonic analysis of $\mathbf{7 2 0}$ hourly heights at Arraial do Cabo, observed tide and meteorological residual starting April 1, 2006.

are considered to be driven in large part by predation [31].

\subsection{Water Masses in the Southeastern Brazilian Shelf}

A brief description of the main water masses in the southeastern Brazilian shelf is presented in this paper. Traditionally, the classification of water masses is made through temperature/salinity diagrams according to their thermohaline circulation. The water masses can be identified according to the geographic region where they arise, and the depth in which they reach the vertical equilibrium [6].

The TW is a warm and salty South Atlantic surface water mass, which at the western boundary is transported southward by the BC. This surface water is formed as a result of the intense radiation and excess of evaporation in respect to precipitation. This water mass is characterized by temperatures above $20^{\circ} \mathrm{C}$ and salinities above $36 \%$ on Brazilian Southeastern coast [32]. The Sub-Antarctic Water is cold and less saline high-latitude water mass and its western boundary layer reaches northward extensions due to advection by the Malvinas Current. These two water masses mix and form the SACW that takes place at the Subtropical Convergence Zone (confluence between the SACW and the Antarctic Circumpolar Current) and it extend as far north as $35^{\circ} \mathrm{S}$. The SACW is associated with sinking and northward transport and is found flowing into the region of pycnocline, with temperatures above $6^{\circ} \mathrm{C}$ and below $20^{\circ} \mathrm{C}$ and salinities between 34.6 and 36 PSS (Practical Salinity Scale). In the Brazilian Southeast the SACW thermohaline circulation is around $20^{\circ} \mathrm{C}$ and 36.2 PSS [32]. The Coastal Water $(\mathrm{CW})$ has the thermohaline characteristics varying according to the annual cycle of river runoff and mixture with offshore waters [33]. The Environment National Council (CONAMA) Resolution 357/2005 that provides the classification of water bodies and environmental guidelines for its framework determines limits for the levels of several chemicals components, including nitrogenous nutrients [16]. We have used temperature and salinity data provided by the Admiral Paulo Moreira Institute of Sea Studies-IEAPM and the water mass thermohaline indices are presented in Table 1.

\subsection{Data}

\subsubsection{In Situ Measurements}

Samples of physical, chemical, and biological surface seawater ( $0.5 \mathrm{~m}$ deep) were collected with a Nansen bottle with reverse thermometer outside, and in the bottom (water/sediment interface), by scuba diving using a 2-1 polyethylene bottle (three samples). The salinity, dissolved oxygen, and nutrients were determined ashore as described in [34]. The method described in [35] was applied to chlorophyll $a$. An inversion thermometer fixed to the outside of a Nansen bottle was employed for temperature. Then the physical and chemical parameters are: Sea Surface Temperature (SST), salinity, dissolved oxygen (DO), nitrogen as ammonium cation $\left(\mathrm{NH}_{4}^{+}\right)$, nitrite $\left(\mathrm{NO}_{2}\right)$ and nitrate $\left(\mathrm{NO}_{3}\right)$, and ortho-phosphate $\left(\mathrm{PO}_{4}\right)$.

The biological variables are composed of chlorophyll $a$ (milligrams per cubic meter) measurements as an estimation of microalgal biomass, but probably also contains all free-living autotrophic bacteria of the water column both influenced qualitatively and quantitatively by nutrient entrances that on the other hand, supplies itself as feeding material for meroplankton larvae which are expressed in numbers of organisms per cubic meter of water and were collected by means drag plankton net of 100 mesh and fixed in $10 \%$ formalin and then counted under a microscope. These data were collected with weekly frequency from July 21, 1999 to June 28, 2007 in Anjos Bay, Arraial do Cabo city, and the nutrients are in accordance with the CONAMA resolution [16].

\subsubsection{Meteo-Oceanographic and Sea Level Data Set}

1) Station measurements

Hourly sea level records for the period 1999-2007 ob- 
Table 1. Southern Brazilian shelf water mass thermohaline indices in Arraial do Cabo.

\begin{tabular}{ccc}
\hline Water Mass & Temperature $\left({ }^{\circ} \mathbf{C}\right)$ & Salinity $(\mathbf{g} / \mathbf{L})$ \\
\hline SACW & $\mathrm{T}<18$ & $\mathrm{~S}<36$ \\
SACW/COASTAL & $18<\mathrm{T}<20$ & $35<\mathrm{S}<36$ \\
COASTAL & $\mathrm{T}>20$ & $\mathrm{~S}<35.4$ \\
SACW/TROPICAL & $18<\mathrm{T}<20$ & $\mathrm{~S}>36$ \\
COASTAL/TROPICAL & $\mathrm{T}>20$ & $35.4<\mathrm{S}<36$ \\
TROPICAL & $\mathrm{T}>20$ & $\mathrm{~S}>36$ \\
\hline
\end{tabular}

tained from the tide gauge station installed at Arraial do Cabo near Anjos Bay at latitude $22^{\circ} 58^{\prime} \mathrm{S}$ and longitude $42^{\circ} 00^{\prime} \mathrm{W}$.

The equipment has been operated and maintained by the IEAPM of Brazilian Navy. The tidal predictions were also supplied for the same period. The meteorological residual was obtained from the difference between the observed and predicted levels. 6-hourly (UTC) atmospheric pressure and direction and wind speed from São Pedro d'Aldeia (SPA) meteorological station were also used.

2) Satellite wind measurements

The QuikSCAT is the first satellite-borne scanning radar scatterometer which measures the surface roughness of the ocean, affected by the wind magnitude and direction, by transmitting microwave pulses $(13.4 \mathrm{GHz})$ and receiving the backscatter. Multiple and simultaneous normalized radar cross-section values are obtained from the backscatter power at a single geographical location or wind vector cell and converted to wind speed and direction measurements (10 m neutral winds) using a Geophysical Model Function [36]. High-resolution QuikSCAT vector wind fields suitable for coastal applications and studying of smaller oceanic processes have been produced by combining scatterometer measurements with a regional mesoscale model [37] or by use of "slices" [38].

The QuikSCAT vector wind product of Remote Sensing Systems (RSS) available daily on a $0.25^{\circ}$ grid was used for the same period, obtained from the National Aeronautics and Space Administration-Jet Propulsion Laboratory_-Physical Oceanography Distributed Active Archive Center.

Direction and wind speed as well as the meteorological residual were calculated from the wind data set and the tide gauge records, respectively. As the surface wind stress provides the most important forcing of the ocean circulation due to the relative motion between the atmosphere and ocean, we used in this work the zonal (ZWS) and meridional wind stress (MWS) calculated by the following equations:

$$
\begin{aligned}
& T_{x}=\rho C_{d}|W| u \\
& T_{y}=\rho C_{d}|W| v
\end{aligned}
$$

where: $\rho=1.22 \mathrm{~kg} \cdot \mathrm{m}^{-3}$ (air density);

$W=$ intensity of the wind $\left(\mathrm{m} \cdot \mathrm{s}^{-1}\right)$ calculated from zonal (u) and meridional (v) wind components; $C_{d}=1.1+$ $0.053 \mathrm{~W}$ (coefficient of drag for the southeast Brazil coast, [39]). The units used for wind stress are $\mathrm{N} \cdot \mathrm{m}^{-2}$, where 1 $\mathrm{hPa}$ is equal to $10^{2} \mathrm{~N} \cdot \mathrm{m}^{-2}$. The meteo-oceanographic time series are then weekly and for the same period as all the others.

In this research the physical, chemical and biological parameters were collected with weekly frequency. Astronomical tides are one of the most evident sea level oscillations, being that the more energetic tides are the semidiurnal (6-hourly periods) and diurnal (12-hourly periods) and therefore this sample period do not represent the tidal influence when compared with others. Due to the meteorological systems have longer periods of oscillation and influence the variations in sea level near the coastline, we only used the meteorological residual.

\subsection{Methodology}

\subsubsection{Statistical Analysis}

The basic statistical analysis was applied in the environmental time series for the period from July 1999 to June 2007. Some outliers were identified and substituted by the average values between the previous and the following weekly data (Table 2).

The number of occurrence of NE and SW wind stress directions was verified. These two directions characterize two important meteorological events in the region. Winds that blow from northeastern due the presence of high pressure systems can result in upwelling events and southwestern winds are related to the passage of cold fronts and cause lowing and rising of the sea level, respectively. Meteorological event leads to the occurrence of positive and negative surges which modify the tidal amplitudes due to interactions between winds, shallow water and bottom friction. The relationship between the seasonal patterns of the residual and biological and chemical parameters was verified in order to evaluate the most significant months for monitoring the region during the critical period of upwelling. From the total data set were extracted those relating to each water masses, according to temperature and salinity. Cross-correlation matrix was then applied to the data set of each water masses and then extracted the relationships between these variables and the residual for each marine environment of interest. The knowledge of trophic relationships in the different water masses seems to be crucial for the success of environmental management policies in coastal aquatic systems. 
Table 2. Statistical summary of the data set.

\begin{tabular}{|c|c|c|c|c|}
\hline Variables & Max & Min & Mean & S. Dev. \\
\hline \multicolumn{5}{|l|}{ Biological } \\
\hline Chlorophill $a\left(\mathrm{mg} / \mathrm{m}^{3}\right)$ & 11.9 & 0.0 & 1.0 & 1.19 \\
\hline Ascidiacea $\left(\mathrm{Org} / \mathrm{m}^{3}\right)$ & 1115 & 0.0 & 11 & 59.5 \\
\hline Bivalvia $\left(\mathrm{Org} / \mathrm{m}^{3}\right)$ & 1833 & 0.0 & 99 & 194.9 \\
\hline Briozoa $\left(\mathrm{Org} / \mathrm{m}^{3}\right)$ & 101 & 0.0 & 2 & 5.7 \\
\hline Cirripedia $\left(\mathrm{Org} / \mathrm{m}^{3}\right)$ & 3641 & 0.0 & 210 & 362.8 \\
\hline Cypris $\left(\mathrm{Org} / \mathrm{m}^{3}\right)$ & 5192 & 0.0 & 22 & 255.5 \\
\hline Decapoda $\left(\mathrm{Org} / \mathrm{m}^{3}\right)$ & 437 & 0.0 & 20 & 35.9 \\
\hline Isognomon $\left(\mathrm{Org} / \mathrm{m}^{3}\right)$ & 2342 & 0.0 & 31 & 166.5 \\
\hline Mytilidae (Org/m³) & 2636 & 0.0 & 93 & 173.9 \\
\hline Polychaeta $\left(\mathrm{Org} / \mathrm{m}^{3}\right)$ & 1683 & 0.0 & 20 & 91.5 \\
\hline Ostreidae $\left(\mathrm{Org} / \mathrm{m}^{3}\right)$ & 1132 & 0.0 & 27 & 76.9 \\
\hline \multicolumn{5}{|l|}{ Sample Water } \\
\hline Temperature $\left({ }^{\circ} \mathrm{C}\right)$ & 26.7 & 15.9 & 22.6 & 1.76 \\
\hline Salinity (g/L) & 36.6 & 33.5 & 35.7 & 0.46 \\
\hline Oxigen (DO) (ml/L) & 7.0 & 2.6 & 5.3 & 0.45 \\
\hline Phosphate $\left(\mathrm{PO}_{4}\right)(\mu \mathrm{mol} / \mathrm{l})$ & 3.7 & 0.0 & 0.3 & 0.21 \\
\hline Nitrite $\left(\mathrm{NO}_{2}\right)(\mu \mathrm{mol} / \mathrm{l})$ & 0.6 & 0.0 & 0.1 & 0.08 \\
\hline Nitrate $\left(\mathrm{NO}_{3}\right)(\mu \mathrm{mol} / \mathrm{l})$ & 10.2 & 0.0 & 0.7 & 0.97 \\
\hline Ammonium $\left(\mathrm{NH}_{4}\right)(\mu \mathrm{mol} / \mathrm{l})$ & 7.8 & 0.1 & 1.2 & 0.79 \\
\hline \multicolumn{5}{|l|}{ Stations } \\
\hline Pressure_SPA (hPA) & 1028.0 & 1003.0 & 1016.0 & 4.65 \\
\hline Wind stress_SPA $\left(\mathrm{N} / \mathrm{m}^{2}\right)$ & 0.3256 & 0.0 & 0.0416 & 0.0512 \\
\hline Tide $(\mathrm{cm})$ & 327 & 178 & 256.7 & 27.99 \\
\hline Meteorological residual $(\mathrm{cm})$ & 51.5 & -48.5 & 2.15 & 15.11 \\
\hline \multicolumn{5}{|l|}{ Satellite (QuickSCAT) } \\
\hline Wind stress_Quick (N/m²) & 0.4442 & 0.0 & 0.0963 & 0.0811 \\
\hline
\end{tabular}

\subsubsection{Multivariate Statistical Analysis}

Cluster analysis is a multivariate technique used to group objects into classes (clusters) on the basis of similarities within a class and dissimilarities between different classes. It is a data classification method. In hierarchical cluster analysis, a dendogram is drawn with samples plotted in clusters on the y axis and linkage distances plotted on the $\mathrm{x}$ axis. The linkage distances between the clusters illustrate relative similarities in the characteristics of the samples. Ward's method was used to form the clusters [40]. This method uses an analysis of variance approach to minimize the sum of squares of any two hy- pothetical clusters. Pearson-r distances were used as the similarity measure. CA is also used to verify the spatial distribution data set and discover groups of similar patterns to describe more clearly the structure and composition of the study area ecosystem. The data set was separated seasonally in spring-summer (upwelling period) and autumn-winter (downwelling period) to characterize which variables are more important in these distinct periods relating them with the sea level variation.

PCA is a technique for mapping multidimensional data into lower dimensions with minimal loss of information. This method can take into account the variability of the data set between different locations (spatial scale) and between successive samples (temporal scale). It is used in all forms of analysis because it is a simple, non-parametric method of extracting relevant information from data sets. Numerical analysis procedures, such as PCA, have been developed to interpret large space/time data sets, which can decompose total variance into spatial and temporal variances. The principal axis method was used to extract the components, and this was followed by an orthogonal rotation [41]. In environmental studies with many physical, chemical and biological variables, one way to evaluate an integrated complex data is multivariate statistical methodology where variables can be analyzed together $[42,43]$. It consists of a linear transformation of all original variables in new variables or components. In such a way, the first computed component is responsible for most of the variance in the observed variables. The second is responsible for the greatest possible variance remaining and so on until all the variance has been explained. PCA is a variable reduction procedure [44]. Then we applied it, which establishes a set of orthogonal factors based on a correlation matrix, providing information about similarities and redundancies of the samples, using Varimax normalized rotation.

\section{Results and Discussion in}

\subsection{Seasonal Variability of the Wind Stress Induced Upwelling}

Wind events induce different disturbances in the water mass structure depending on the season. In Arraial do Cabo coastline, when NE-wind events increase the intensity for a period, mixing with the water column, the response is the SACW upwelling with capacity of a redistribution of nutrients with effects on plankton dynamics. Considering the seasonality of the wind events that modulates the zonal and meridional wind field, we also verified the number of occurrence of NE and SW wind stress (Figure 7).

The number of occurrence of SW wind direction is similar at SPA and Q, around $11 \%$ and $12 \%$, respectively. This result shows the small quantify of frontal systems 
that reach the region. Although SPA station presents higher percentage than satellite data set for NE direction, the values are very close between them, around $71 \%$ and $62 \%$, respectively. These results show that the Quick Scatterometer winds are also a good source of data set for this coastal area. The predominance of NE winds indicates the seasonal variability of the South Atlantic high pressure system that leads upwelling in this region. Therefore the monitoring of this area is important due to the effects that this phenomenon causes in the local biodiversity and economy.

\subsection{Seasonal Variability of the Residual and Chemical and Biological Parameters}

The seasonality of the mean residual presents a welldefined pattern with maximum peaks in the months of autumn and winter. It can be related to the presence of cold fronts that although they reach the region with no much frequency, they are more intense in this period. Another important aspect in raising the sea level is the internal waves due to the interaction of currents, such as barotropic tides and wind-induced flows, including seabed topography near the continental shelf [45]. Minimum during spring with negative values and summer can be related to the prevailing of the South Atlantic high-pressure with E-N winds blowing offshore the coastline and consequently occurrence of coastal upwelling (Figure 8). Seasonal variations were then compared between mean

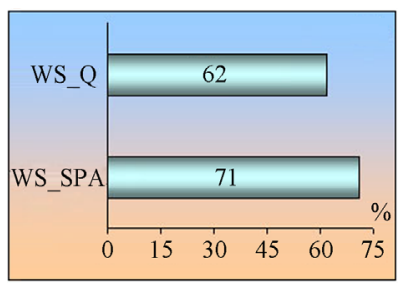

(a)

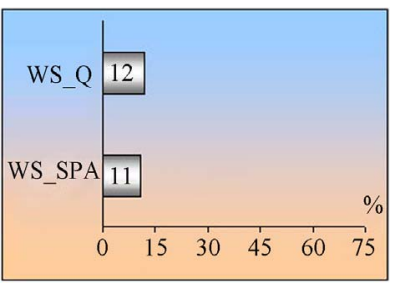

(b)
Figure 7. Number of occurrence of NE (a) and SW (b) wind direction verified at SPA weather station and vector wind obtained by Quick Scatterometer (Q).

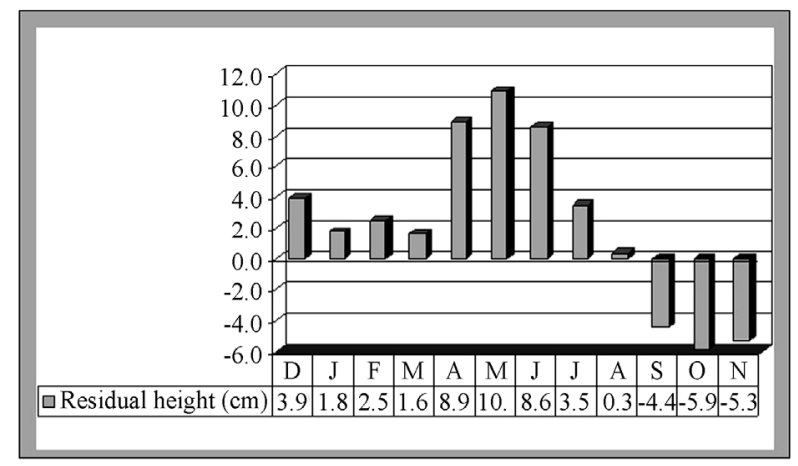

Figure 8. Seasonal distribution of the mean values meteorological residual. residual, total nitrogen $\left(\mathrm{NO}_{2}, \mathrm{NO}_{3}\right.$, and $\left.\mathrm{NH} 4\right), \mathrm{DO}, \mathrm{PO}_{4}$, and peaks of maximum values of larvae. Figure 9 shows an increasing of biological and chemical variables in spring/summer and a minimum of residual which may take place due to the meteorological system previous described. The opposite is verified in autumn/winter with minimum peaks in April and May. However we can verified that Cirripedia and Polychaeta present maximum in July. In this month verifies the presence of the TW mass which at the western boundary is transported southward by the BC [16]. Cirripedia are sessile invertebrate organisms (barnacles) that cover substantial area of the substratum on intertidal and subtidal zones. They live in warm and shallow water and are important in determining and monitoring environmental impacts in coastal areas [46]. Although there are no further reports of economic damage, it is known that the hulls of ships, oil platforms, pipelines and other plant artificial substrates available in the marine environment may be completely covered by the barnacles causing corrosion of metals and an increase in maintenance costs [47]. The Polychaeta is a bristle-worm with species that live in the coldest ocean temperatures and other which tolerate the extreme high temperatures. An inventory of the species found on the beaches of Rio de Janeiro State, Brazil was made by [48].

\subsection{Cross-Correlations for Different Water Masses}

As shown in Table 1, we have used temperature and salinity data (thermohaline indices) to classify the water mass. Thus, the data set were separated according to this criterion and applied cross-correlation to verify the relationship between the biological, chemical and physical parameters. Table 3 shows these correlations that were verified only for Central Water (SACW), Central/Coastal Water (SACW/CW) and Central/Tropical Water (SACW/ TW). These correlations verified in the presence of SACW show the importance of this water mass in the coastal upwelling process. In other water masses these variables did not present correlations. Correlation between the residual and the variables in presence of SACW suggest a sensitivity of microorganisms as Bivalvia (Class of mussels), Mytilidae (Family of mussels), and Ostreidae (oysters) associated, likely, with the decrease of the residual due the presence of the South Atlantic Subtropical High (SASH) for the upwelling period with E-NE wind direction. A direct and inverse correlation is verified for Chlorophyll $a(0.90)$ and Salinity $(-0.89)$, respectively. The residual also presents direct correlation with the nutrients $\mathrm{PO}_{4}, \mathrm{NO}_{2}$ and $\mathrm{NO}_{3}$ for the $\mathrm{SACW}$ in the presence of $\mathrm{CW}$. This leads to a linear relationship between them, which can suggest a relation to a discharge of water on the coastline. Chlorophyll $a$, As- 


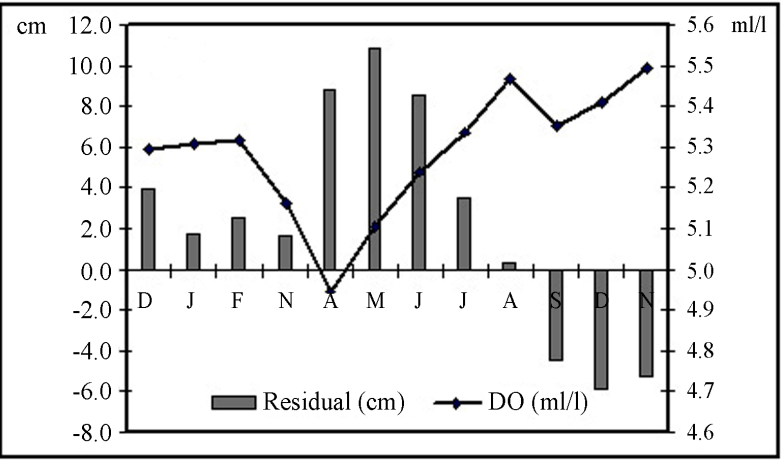

(a)

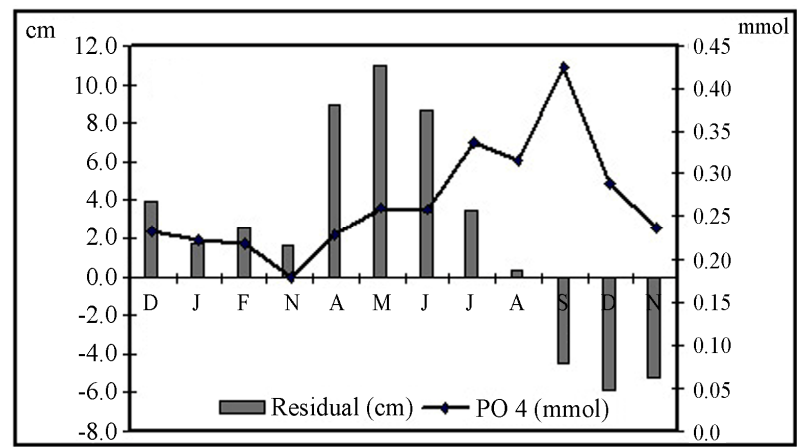

(c)

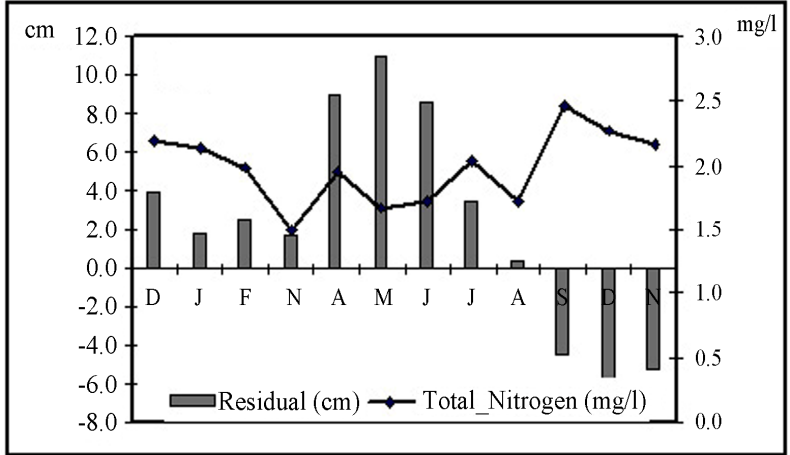

(b)

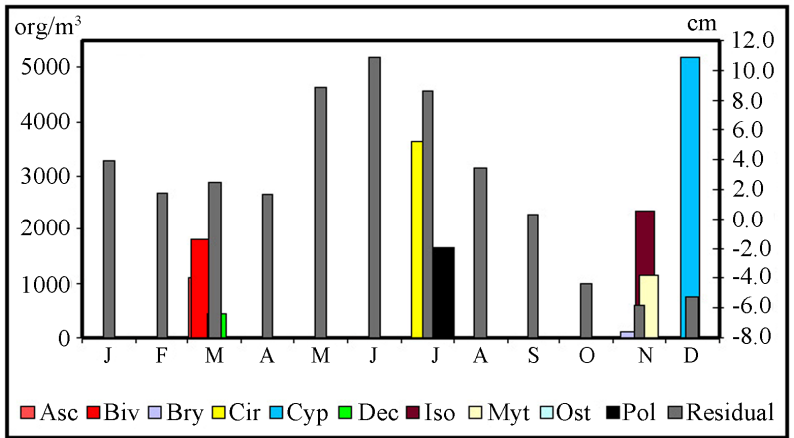

(d)

Figure 9. Seasonal variability of (a) DO, (b) total nitrogen $\left(\mathrm{NO}_{2}, \mathrm{NO}_{3}\right.$, and $\left.\mathrm{NH}_{4}\right)$, (c) $\mathrm{PO}_{4}$, and (d) peaks of maximum values of larvae for 1999-2007 period.

cidiacea, Cypris, Decapoda (-0.77), Polychaeta present a negative correlation with the residual, showing a sensibility of these larvae with sea level variations due to meteorological forcing. For the SACW/TW, the residual presents more correlations with the chemical and biological variables. An inverse correlation with Chlorophyll $a$, DO, nutrients, Cirripedia, Cypris and Decapoda $(-0.92)$, suggest also a relation to the same construct. Ascidiacea, Cirripedia and Cypris present correlations for SACW/CW and SACW/TW and are important in studies on recruitment as well as determining and monitoring environmental impacts in coastal regions.

Bivalve mollusks, particularly marine mussels, correlated in presence of SACW $(-0.63)$ have been used as indicator organisms in environmental monitoring programmers due to their wide distribution, sedentary lifestyle, tolerance to a large range of environmental conditions and because they are filter-feeders with very low metabolism which allows the bioaccumulation of many chemicals in their tissues [49].

\subsection{Multivariate Statistical Analysis}

Data grouped according to the CA were performed to verify the structure and composition of the regional ecosystem. There are many available algorithms for this task and here we used for the Ward method with Pearson-r coefficient. Figure 10 illustrates the results of cluster analysis that grouped the sampling points in two big clusters, one of biotic variables in one side and abiotic ones at the other, corresponding to the macrostructure of ecosystem.

The Pearson-r distance was chosen as the similarity measurement, between sampling sites and Ward's method to form clusters were more successful compared to other methods. Ward's method is distinct from all other linkage rules because it uses an analysis of variance approach to evaluate the distances between clusters, producing the most distinctive groups [50]. The classification of the samples into clusters is based on a visual observation of the dendrogram at a linkage distance of about line 1.2 (Figure 10). Thus, samples with a linkage distance lower than line 1.2 allows a division of the dendrogram into six clusters, reaching the objectives of the classification method. The degree of refinement of similarities can be written as $\mathrm{C}_{1}$ (family of oysters and mollusks, genus of marine bivalve mollusks and Bryosoa (phylum of aquatic invertebrate animals as moss animals)), $\mathrm{C}_{2}$ (classes of barnacles, worms, tunicate, class of mussels and order of crustaceans), $\mathrm{C}_{3}$ (wind), $\mathrm{C}_{4}$ (nitrogen concentration, phosphorus and pressure), $\mathrm{C}_{5}$ (DO, Chloro $a$ and ostracods (a type of crustacean) $\mathrm{C}_{6}$ (Temperature, Residual, Salinity and ammonium). This CA shows the importance 
Table 3. Correlation between the residual and Chemical, Biological and Physical variables (95\% confidence interval).

\begin{tabular}{|c|c|c|c|}
\hline \multirow{2}{*}{ Variable } & \multicolumn{3}{|c|}{ Residual } \\
\hline & SACW & $\mathrm{SACW} / \mathrm{CW}$ & $\mathrm{SACW} / \mathrm{TW}$ \\
\hline Sal & -0.89 & $\mathrm{x}$ & $\mathrm{x}$ \\
\hline Chl $a$ & 0.90 & -0.38 & -0.47 \\
\hline DO & $\mathrm{x}$ & $\mathrm{x}$ & -0.57 \\
\hline $\mathrm{NO}_{2}$ & $\mathrm{x}$ & 0.61 & -0.34 \\
\hline $\mathrm{NO}_{3}$ & $\mathrm{x}$ & 0.58 & -0.60 \\
\hline $\mathrm{NH}_{4}$ & 0.40 & $\mathrm{x}$ & -0.69 \\
\hline $\mathrm{PO}_{4}$ & $\mathrm{x}$ & 0.50 & -0.44 \\
\hline Asc & $\mathrm{x}$ & -0.47 & $\mathrm{x}$ \\
\hline Biv & -0.63 & $\mathrm{x}$ & $\mathrm{x}$ \\
\hline Cirr & $\mathrm{x}$ & $\mathrm{x}$ & -0.62 \\
\hline Сур & $\mathrm{x}$ & -0.56 & -0.47 \\
\hline Deca & $\mathrm{x}$ & -0.77 & -0.92 \\
\hline Myti & -0.62 & $\mathrm{x}$ & -0.42 \\
\hline Ost & -0.63 & $\mathrm{x}$ & $\mathrm{x}$ \\
\hline Poly & $\mathrm{x}$ & -0.68 & $\mathrm{x}$ \\
\hline WS_X_Q & -0.48 & $\mathrm{x}$ & $\mathrm{x}$ \\
\hline WS_X_SPA & $\mathrm{x}$ & $\mathrm{x}$ & -0.46 \\
\hline WS_Y_SPA & $\mathrm{x}$ & $\mathrm{x}$ & -0.47 \\
\hline WS_Y_Q & $x$ & $\mathrm{x}$ & -0.78 \\
\hline
\end{tabular}

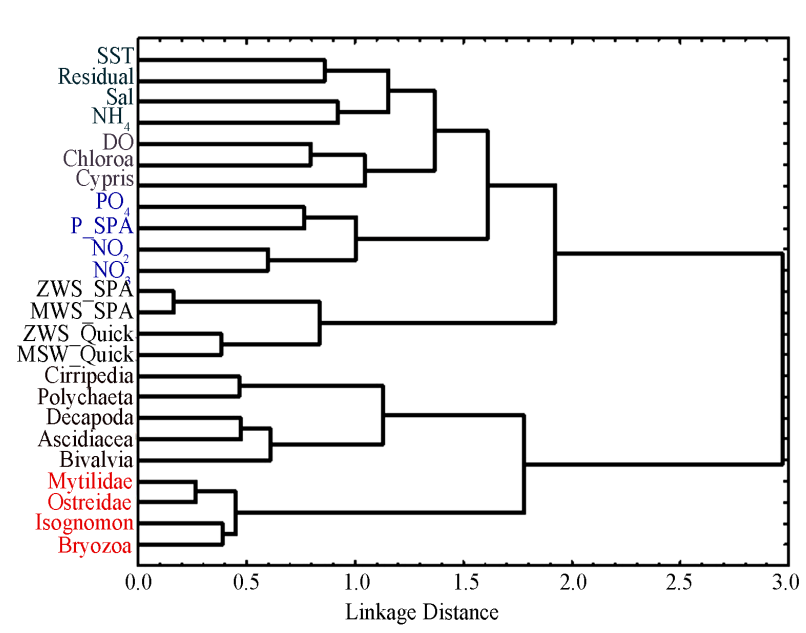

Figure 10. Dendogram for 24-variables illustrating the result of the cluster analysis. Different clusters are indicated by the different colors $\left(C_{1}-C_{6}\right)$.

of the zonal and meridional wind variability, including these variables in a single cluster as noted in the first two factors of PCA. In reality, the number of components extracted in a PCA is equal to the number of observed variables being analyzed. This means that an analysis of $\mathrm{N}$ variables would actually result in $\mathrm{N}$ components. However, in most analyses, only the first few components account for meaningful amounts of variance, so only these first few components are retained and interpreted. In the present study were performed on 24-variables and only eight components were extracted with this criterion. The first component can be expected to have large amount of the total variance. Each succeeding component will account for progressively smaller amounts of variance. Therefore, only the first eight components were retained and they explain $64.10 \%$ of the total variance in the data set. The first three components were the most important, with $15.7 \%, 11.3 \%$ and $8.6 \%$ of explained variance (Table 4). The first component was attributed to larvae that had the greatest variability with scores strongly positively correlated to Mytilidae, Decapoda, Bivalvia, Ostreidae, Isognomon and Bryosoa. This statistical strategy gives greater importance to the larvae in the ordering and feature extraction of the coastal ecosystem, being then denominated here "biotic component" that corresponds to the major larvae economically important to the region as crustaceans, mussels and oysters. The second component was strongly negatively correlated with zonal and meridional wind from SPA and satellite and relatively weak with meteorological residual $(r$ $=-0.40$ ), showing the interaction sea-air and therefore denominated "wind component". The third component was attributed to temperature and nutrients. It showed a strong positive correlation with SST and relatively weak positive loading on $\mathrm{PO}_{4}, \mathrm{NO}_{2}$ and $\mathrm{NO}_{3}$. These abiotic variables characterize the local marine ecosystem and are related to the presence of different water masses. Then this component was denominated here "water masses component" and it can explain the presence of SACW that is very important in upwelling periods. The factor loading of these three components accounts for $35.6 \%$ of variance and the other factors are restrict to a few parameters with low variance, indicating that they do not account for great variations. The fourth factor that contributes with a small variance of $7.5 \%$ also relates to the biotic components of the classes of zoobenthos (Cirripedia, Polychaeta and Ascidiacea) found in intertidal zones [51]. The ascidiaceas, for example, are larvae bioindicators that react to environmental changes with high filtration, playing a significant role in water purification. They influence the amount of nutrients and pollutants in suspension $[52,53]$. But they grow rapidly and have a long reproduction period, becoming invasive potential, contributing to incrustation in the port regions [54]. Figure 11 illustrates the three principal components. The dendrogram produced by this approach is close to the PCA components. Some clusters and loadings have the same 
Table 4. Correlation between the residual and chemical, biological and physical variables $(95 \%$ confidence interval).

\begin{tabular}{|c|c|c|c|c|}
\hline Factor loading & Factor 1 & Factor 2 & Factor 3 & Factor 4 \\
\hline SST & 0.105 & -0.012 & 0.716 & 0.140 \\
\hline Sal & 0.020 & 0.121 & 0.259 & -0.023 \\
\hline DO & -0.048 & -0.064 & -0.306 & -0.012 \\
\hline $\mathrm{PO}_{4}$ & -0.111 & -0.056 & -0.532 & -0.192 \\
\hline $\mathrm{NO}_{2}$ & -0.128 & -0.153 & -0.560 & -0.248 \\
\hline $\mathrm{NO}_{3}$ & -0.110 & -0.016 & -0.535 & -0.232 \\
\hline $\mathrm{NH}_{4}$ & -0.112 & 0.096 & -0.042 & 0.014 \\
\hline Chloro a & -0.070 & -0.115 & -0.158 & -0.034 \\
\hline Cirripedia & 0.383 & -0.054 & 0.115 & -0.535 \\
\hline Mytilidae & 0.785 & -0.251 & -0.188 & 0.257 \\
\hline Decapoda & 0.607 & -0.220 & 0.126 & -0.368 \\
\hline Polychaeta & 0.326 & -0.111 & 0.066 & -0.583 \\
\hline Bivalvia & 0.668 & -0.063 & 0.117 & -0.259 \\
\hline Ostreidae & 0.789 & -0.251 & -0.112 & 0.187 \\
\hline Cypris & 0.079 & -0.045 & 0.033 & -0.105 \\
\hline Ascidiacea & 0.387 & -0.057 & 0.240 & -0.519 \\
\hline Isognomon & 0.715 & -0.197 & -0.132 & 0.376 \\
\hline Bryozoa & 0.595 & -0.274 & -0.247 & 0.479 \\
\hline Residual & -0.194 & -0.400 & 0.149 & 0.073 \\
\hline ZWS_SPA & -0.310 & -0.787 & 0.090 & -0.064 \\
\hline MWS_SPA & -0.290 & -0.765 & 0.095 & -0.067 \\
\hline P_SPA & 0.010 & -0.083 & -0.439 & -0.150 \\
\hline ZWS_Quick & -0.278 & -0.672 & 0.150 & 0.056 \\
\hline MSW_Quick & -0.281 & -0.718 & 0.028 & 0.015 \\
\hline Eigenvalue & 3.773 & 2.711 & 2.069 & 1.794 \\
\hline Variability (\%) & 15.722 & 11.296 & 8.619 & 7.474 \\
\hline Cumulative (\%) & 15.722 & 27.019 & 35.638 & 43.112 \\
\hline
\end{tabular}

variables, such as $\mathrm{C}_{1}, \mathrm{C}_{2}, \mathrm{C}_{3}$ and $\mathrm{C}_{4}$ with Factor 1, 2, 3 and 4 , corresponding to the importance of the biological variables and local environmental structure.

\section{Conclusions}

Seasonal variability of the mean meteorological residual presents a well-defined pattern with maximum peaks in autumn and winter and minimum during spring and summer, showing the meaningful meteorological patterns

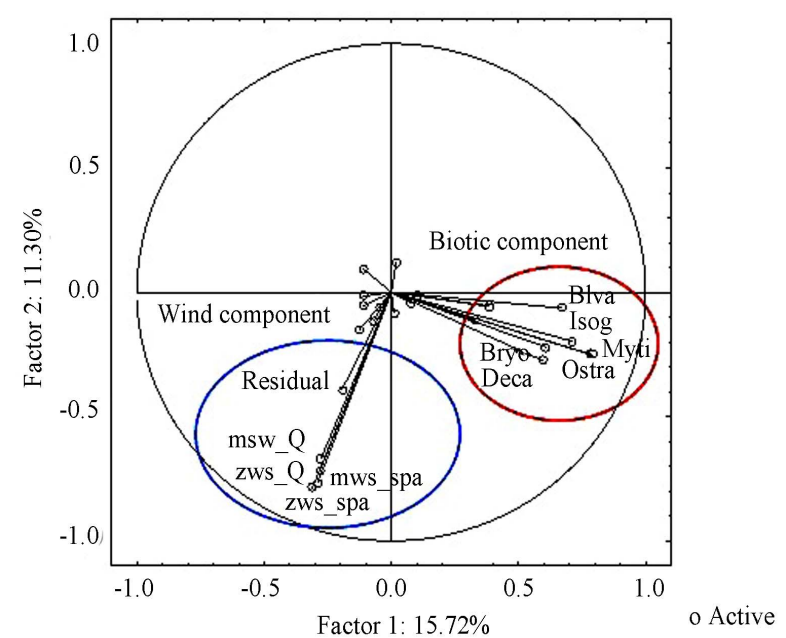

(a)

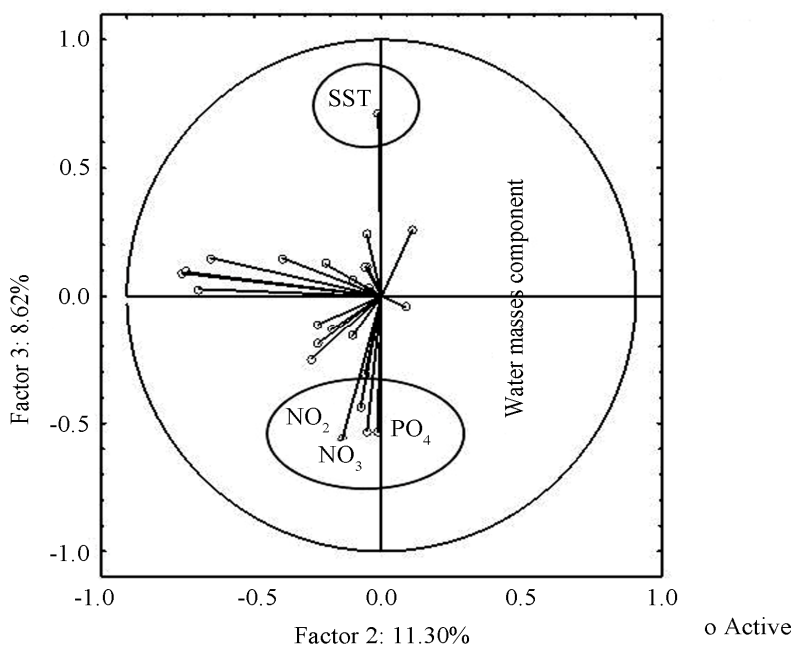

(b)

Figure 11. Plot of loadings for the first two components (a), third component (b) with Varimax normalized rotation.

that occur in the region. Comparing the seasonal variations between mean residual, total nitrogen $\left(\mathrm{NO}_{2}, \mathrm{NO}_{3}\right.$, and $\mathrm{NH} 4), \mathrm{DO}, \mathrm{PO}_{4}$ and larvae we verify that the critical months with lower values of the residual occur in August, September, October and November. Ascending values of DO are verified from August with maximum peak in November. Total nitrogen and $\mathrm{PO}_{4}$ present high values from September with maximum peaks. However the larvae present peaks in March to Bivalvia, Ascidiacea and Decapoda; July to Cirripedia and Polychaeta when verifies the presence of the TW; November to Bryosoa, Isognomon, Mytilidae and Ostreidae and December to Cypris, period of occurrence of upwelling.

The cross-correlations between meteorological residual and the biological and chemical variables for different water masses present correlations only in the presence of Central Water (SACW), showing the importance of this water mass in the coastal upwelling process. 
CA grouped the sampling in two big clusters, one of biotic variables in one side and abiotic ones at the other, corresponding to the macrostructure of ecosystem. The degree of refinement of similarities allowed a division into six clusters of samples, giving the most satisfactory results at forming distinct clusters, reaching thus the objectives of the classification method. This cluster analysis shows the importance not only the biotic variables but also of the zonal and meridional wind variability, including these variables in a single cluster.

PCA retained and interpreted eight components and they explain $64.10 \%$ of the total variance in the data set. The first component was attributed to larvae that had the greatest variability with scores strongly positively correlated, corresponding to the major larvae economically important to the region as crustaceans, mussels and oysters. The second component was strongly negatively correlated with zonal and meridional wind both with the SPA station and with satellite wind data and relatively weak with meteorological residual, showing the sea-air coupling. The third component was attributed to temperature and nutrients, characterizing the local marine ecosystem related to the presence of different water masses. The fourth factor contributes with a small variance and also relates to the biotic components of the classes of zoobenthos (Cirripedia, Polychaeta and Ascidiacea) found in intertidal zones.

The applied methodology shows the relationship between biological and chemical variables and meteorological processes in the main Brazilian region where upwelling occurs, contributing to the improvement of models of coastal management.

\section{Acknowledgements}

The authors thank the Admiral Paulo Moreira Institute of Marine Studies-IEAPM of Brazilian Navy for data availability and logistical support. The authors also thank the financial support of the Coordination for the Improvement of Higher Level Personnel-Brazilian Research Agency (Capes).

\section{REFERENCES}

[1] P. M. S. Monteiro, G. Nelson, A. van der Plas, E, Mabille, G. W. Baileyd and E. Klingelhoeffer, "Internal Tide-Shelf Topography Interactions as a Forcing Factor Governing the Large-Scale Distribution and Burial Fluxes of Particulate Organic Matter (POM) in the Benguela Upwelling System," Continental Shelf Research, Vol. 25, No. 15, 2005, pp. 1864-1876.

http://dx.doi.org/10.1016/j.csr.2005.06.012

[2] P. M. A. B. Ré, "Biologia Marinha," Faculdade de Ciências da Universidade de Lisboa, Portugal, 2000.

[3] B. Boehm and S. B. Weisberg, "Tidal Forcing of Entero- cocci at Marine Recreational Beaches at Fortnightly and Semidiurnal Frequencies," Environmental Science Technology, Vol. 39, No. 15, 2006, pp. 5575-5583.

[4] F. Pereira, A. L. Belém, M. C. Belmiro and R. Geremias, "Tide-Topography Interaction along the Eastern Brazilian Shelf," Continental Shelf Research, Vol. 25, No. 12-13, 2005, pp. 1521-1539. http://dx.doi.org/10.1016/j.csr.2005.04.008

[5] S. A. Piontkovski, M. R. Landry, Z. Z. Finenko, A. V. Kovalev, R. Williams, C. P. Gallienne, A. V. Mishonov, V. A. Skryabin, Y. N. Tokarev and V. N. Nikolsky, "Plankton Communities of the South Atlantic Anticyclonic Gyre: Communautés Planctoniques du Tourbillon Anticyclonique de l'Atlantique Sud," Oceanologica Acta, Vol. 26, No. 3, 2003, pp. 255-268. http://dx.doi.org/10.1016/S0399-1784(03)00014-8

[6] R. H. Stewart, "Introduction to Physical Oceanography," Texas A \& M University, 2007.

[7] D. T. Pugh, "Changing Sea Levels: Effects of Tides, Weather and Climate," Cambridge University Press, 2005, $265 \mathrm{p}$.

[8] S. Franco, "Tides: Fundamentals Analysis and Prediction," IPT, São Paulo, 1981.

[9] N. A. Pore, "The Relation of Wind and Pressure to Extratropical Storm Surge at Atlantic City," Journal of Applied. Meteorology, Vol. 3, No. 2, 1964, pp. 155-163.

[10] D. T. Pugh, "Tides, Surges and Mean Sea Level," John Wiley \& Sons, 1987, $472 \mathrm{p}$.

[11] D. Prandle and J. Wolf, "The Interaction of Surge and Tide in the North Sea and River Thames," Geophysical Journal of the Royal Astronomical Society, Vol. 55, No. 1, 1978, pp. 203-216.

[12] J. Wolf, "Surge-Tide Interaction in the North Sea and River Thames, in Floods due to High Winds and Tides," Elsevier, New York, 1981, pp. 75-94.

[13] K. J. Horsburgh and C.Wilson, "Tide-Surge Interaction and its Role in the Distribution of Surge Residuals in the North Sea," Journal of Geophysical Research, Vol. 112, No. C8, 2007, pp. 1-13.

http://dx.doi.org/10.1029/2006JC004033

[14] K. Myrberg, O. Andrejev and A. Lehmann, "Dynamic Features of Successive Upwelling Events in the Baltic Sea-A Numerical Case Study," Oceanologia, Vol. 52, No. 1, 2010, pp. 77-99. http://dx.doi.org/10.5697/oc.52-1.077

[15] M. M. F. de Oliveira, N. F. Ebecken, de J. L. F. Oliveira and I. A. Santos, "Neural Network Model to Predict a Storm Surge," Journal of Applied Meteorology and Climatology, Vol. 48, No. 1, 2009, pp. 143-155. http://dx.doi.org/10.1175/2008JAMC1907.1

[16] M. M. F. de Oliveira, G. C. Pereira, J. L. F. de Oliveira and N. F. F. Ebecken, "Large and Mesoscale MeteoOceanographic Patterns in Local Responses of Biogeochemical Concentrations," Environmental Monitoring and Assessment, Vol. 184, No. 1, 2012, pp. 6935-6953. http://dx.doi.org/10.1007/s10661-011-2470-3

[17] E. D. Campos, J. L. Miller, T. J. Muller and R. G. Peterson, "Physical Oceanography of the Southwest Atlantic 
Ocean," Oceanography, Vol. 8, No. 3, 1995, pp. 87-91.

[18] L. P. Pezzi, "Variabilidade do Sistema Oceano-Atmosfera no Oceano Atlântico Sudoeste," I Seminário Sobre Sensoriamento Remoto Aplicado à Pesca, INPE, S: J: dos Campos, 2006.

[19] M. A. Guimaraens and R. Coutinho, "Spatial and Temporal Variation of Benthic Marine Algae at the Cabo Frio Upwelling Region," Aquatic Botany, Vol. 52, No. 4, 1996, pp. 283-299. http://dx.doi.org/10.1016/0304-3770(95)00511-0

[20] G. C. Pereira, R. Coutinho and N. F. F. Ebecken, "Data Mining for Environmental Analysis and Diagnostic: A Case Study of Upwelling Ecosystem of Arraial do Cabo," Brazilian Journal of Oceanography, Vol. 56, No. 1, 2008, pp. 1-18.

[21] C. D. Ahrens, "Meteorology Today: An Introduction to Weather Climate and the Environment," 6th Edition, Brooks/Cole, London, 2000.

[22] R. B. de. Souza, "Oceanografia por Satélites," 2nd Edition, Oficina de Textos, São Paulo, 2008.

[23] S. A.Gaeta, J. A. Lorenzetti, L. B. Miranda, S. M. M. Susimi-Ribeiro, M. Pompeu and C. E. S. Araújo, "The Vitória Eddy and Its Relation to the Phytoplankton Biomass and Primary Production during the Austral Fall of 1995," Archive of Fishery and Marine Research, Vol. 47, No. 2-3, 1999, pp. 253-270.

[24] R. P. Matano, M. Schlax and D. B. Chelton, "Seasonal Variability in the Southwestern Atlantic," Journal of Geophysical Research, Vol. 98, No. C10, 1993, pp. 18027- 18035.

[25] M. L. G. Rodrigues, D. Franco and S. Sugahara, "Climatologia de Frentes Frias no Litoral de Santa Catarina," Revista Brasileira de Geofisica, Vol. 22, No. 2, 2004, pp. 135-151.

http://dx.doi.org/10.1590/S0102-261X2004000200004

[26] J. L. Valentin, "The Dynamics of Plankton in the Cabo Frio Upwelling," In: F. P. Brandini, Ed., Memórias do III EBP, Caiobá-Curitiba, 1989.

[27] D. Topcu, H. Behrendt, U. Brockmann and U. Claussen, "Natural Background Concentrations of Nutrients in the German Bight Area (North Sea)," Environment Monitoring and Assessment, Vol. 174, No. 1-4, 2010, pp. 361-388. http://dx.doi.org/10.1007/s10661-010-1463-y

[28] R. P. Morgan and K. M. Kline, "Nutrient Concentrations in Maryland Non-Tidal Streams," Environment Monitoring and Assessment, Vol. 178, No. 1-4, 2011, pp. 221-235. http://dx.doi.org/10.1007/s10661-010-1684-0

[29] M. Ribas-Ribas, J. M. Hernández-Ayón, V. F. Camacho-Ibar, A. Cabello-Pasini, A. Mejia-Trejo, R. Durazo, S. Galindo-Bect, A. J. Souza, J. M. Forja and A. SiqueirosValencia, "Effects of Upwelling, Tides and Biological Processes on the Inorganic Carbon System of a Coastal Lagoon in Baja California," Estuarine, Coastal and Shelf Science, Vol. 95, No. 4, 2011, pp. 367-376. http://dx.doi.org/10.1016/j.ecss.2011.09.017

[30] R: N. Gibson, "Go with the Flow: Tidal Migration in Marine Animals," Hydrobiologia, Vol. 503, No. 1-3, 2003, pp. 153-161.
http://dx.doi.org/10.1023/B:HYDR.0000008488.33614.6 $\underline{2}$

[31] J. K. Breckenridge and S. M. Bollens, "Vertical Distribution and Migration of Decapod Larvaein Relation to Light and Tides in Willapa Bay," Estuaries and Coasts, Vol. 34, No. 6, 2011, pp. 1255-1261.

http://dx.doi.org/10.1007/s12237-011-9405-7

[32] C. A. Silveira, A. C. K. Schimidt, E. J. D. Campos, S. S. Godoi and Y. Ikeda, "The Brazil Current off the Eastern Brazilian Coast," Brazilian Journal of Oceanography, Vol. 48, No. 2, 2000, pp. 171-183. http://dx.doi.org/10.1590/S1413-77392000000200008

[33] I. Soares and O. M.oller Jr., "Low-Frequency Currents and Water Mass Spatial Distribution on the Southern Brazilian Shelf," Continental Shelf Research, Vol. 21, 2001, pp. 1785-1814.

[34] SCOR, "Protocols for the Joint Global Ocean Flux Study (JGOFS) Core Measurements," Scientific Committee on Ocean Research, International Council of Scientific Unions, Bergen, Vol. 9, 1996, 170 p.

[35] T. A. Richard and T. G. Thompson, "The Estimation and Characterization of Plankton Population by Pigment Analyses. A Spectrophotometric Method for the Estimation of Plankton Pigments," Journal of Marine Research, Vol. 11, 1952, pp. 156-172.

[36] N. Sharma and E. D'Sa, “Assessment and Analysis of QuikSCAT Vector Wind Products for the Gulf of Mexico. A Long-Term and Hurricane Analysis," Sensors, Vol. 8, No. 3, 2008, pp. 1927-1949. http://dx.doi.org/10.3390/s8031927

[37] Y. Chao, Z. Li, J. C. Kindle, J. D. Paduan and F. P. Chavez, "A High-Resolution Surface Vector Wind Product for Coastal Oceans: Blending Satellite Scatterometer Measurements with Regional Mesoscale Atmospheric Model Simulations," Geophysical Research Letters, Vol. 30, No. 1, 2003, pp. 1-13. http://dx.doi.org/10.1029/2002GL015729

[38] W. Tang, W. T. Liu and B. W. Stiles, "Evaluation of High-Resolution Ocean Surface Vector Winds Measured by QuikSCAT Scatterometer in Coastal Regions," IEEE Transactions on Geoscience and Remote Sensing, Vol. 42, No. 8, 2004, pp. 1762-1769. http://dx.doi.org/10.1109/TGRS.2004.831685

[39] J. L Stech and J. A. Lorenzzetti, "The Response of the South Brazil Bight to the Passage of Wintertime Cold Fronts," Journal of Geophysics Research, Vol. 97, No. C6, 1992, pp. 9507-9520.

[40] S. Sharma, "Applied Multivariate Techniques," John Wiley and Sons, Inc., New York, 1996.

[41] H. Abdi and L. J. Williams, "Principal Component Analysis," Wiley Interdisciplinary Reviews: Computational Statistics, Vol. 2, No. 4, 2010, pp. 387-515. http://dx.doi.org/10.1002/wics.101

[42] N. Ruggieri, M. Castellano, M. Capello, S. Maggi and P. Povero, "Seasonal and Spatial Variability of Water Quality Parameters in the Port of Genoa, Italy, from 2000 to 2007," Marine Pollution Bulletin, Vol. 62, No. 2, 2011, pp. 340-349. 
http://dx.doi.org/10.1016/j.marpolbul.2010.10.006

[43] M. Ujević Bošnjak, K. Capak, A. Jazbec, C. Casiot, L. Sipos, V. Poljak and Ž. Dadić, "Hydrochemical Characterization of Arsenic Contaminated Alluvial Aquifers in Eastern Croatia Using Multivariate Statistical Techniques and Arsenic Risk Assessment," Science of the Total Environment, Vol. 420, 2012, pp. 100-110. http://dx.doi.org/10.1016/j.scitotenv.2012.01.021

[44] J. V. E. Bernardi, L. D. Lacerda, J. G. Dórea, P. M. B. Landim, J. P. O. Gomes, R. Almeida, A. G. Manzatto and W. R. Bastos, "Aplicação da Análise das Componentes Principais na Ordenação dos Parâmetros Físico-Quimicos no Alto Rio Madeira e Afluentes, Amazônia Ocidenta," Geochimica Brasiliensis, Vol. 23, No. 1, 2009, pp. 79-90.

[45] A. Stigebrandt, "Resistance to Barotropic Tidal Flow in Straits by Baroclinic Wave Drag," Journal of Physical Oceanography, Vol. 29, No. 2, 1999, pp. 191-197.

[46] M. Apolinário, "Variation of Populations Densities between Two Species of Barnacles (Cirripedia: Megab- alaninae) at Guanabara Bay and Nearly Islands in Rio de Janeiro/RJ," Nauplius, Vol. 9, No. 2, 2001, pp. 21-30.

[47] M A. Champ and F. L. Lowenstein, "TBT-The Dilemma of High-Technology Antifouling Paints," Oceanus, Vol. 35, 1987, pp. 69-77.

[48] M. B. Rocha, V. Radashevsky and P. C. Paiva, "Espécies de Scolelepis (Polychaeta, Spionidae) de Praias do Estado do Rio de Janeiro, Brasil," Biota Neotrópica, Vol. 9, No. 4, 2009.
http://dx.doi.org/10.1590/S1676-06032009000400012

[49] S. M. Lima, J. R. Moreira, A. V. Von Osten, M. Soares and L. Guilhermino, "Biochemical Responses of the Marine Mussel Mytilus galloprovincialis to Petrochemical Environmental Contamination along the North-Western Coast of Portugal," Chemosphere, Vol. 66, No. 7, 2007, pp. 1230-1242. http://dx.doi.org/10.1016/i.chemosphere.2006.07.057

[50] StatSoft Inc., "Statistica," Data Analysis Software System, version 7, 2004.

[51] B. Torrano-Siva, "Fitobentos (Macoalgas) in: Informe Sobre as Espécies Exóticas Invasoras Marinhas no Brasil," Ministério do Meio Ambiente, MMA, 2009.

[52] S. A. Narandio, J. L. Carvalho and J. C. García-Gomes, "Effects of Environmental Stress on Ascidians Populations in Algeciras bay (Southerm Spain)," Marine Ecology, Vol. 144, 1996, pp. 119-131.

[53] T. C. C. Lambert and G. Lambert, "Non-Indigenous Ascidians In southerm California Harbors and Marinas," Marine Biology, Vol. 130, No. 4, 1998, pp. 675-688. http://dx.doi.org/10.1007/s002270050289

[54] R. P. M. Bak, M. Joenje, I. De Jong, D. Y. M. Lambrechts and M. L. J. Van Veghel, "Long-Term Changes on Coral Reef in Booming Populations of a Competitive Colonial Ascidian," Marine Ecology, Vol. 133, 1996, pp. 303-306. http://dx.doi.org/10.3354/meps133303 